\section{Four Models of Growth}

\section{Arthur M. Hauptman}

Arthur M. Hauptman is a public policy consultant specializing in higher education finance issues. This article is from a paper on strategies to meet tertiary challenges prepared for the Higher Education Authority in Ireland. E-mail: hauptman_a@yahoo.com.

$\mathrm{O}$ ver the past half century, more than a dozen countries around the world have employed varying strategies to move from elite systems of tertiary education to mass or universal ones, enrolling at least half of the traditional college-age population. Examining the strategies employed helps to assess how these and other countries in the future may keep up with a burgeoning demand derived from the increasing economic returns through additional postsecondary education and training. A review of the strategies employed suggests four models of growth.

\section{MOdel ONE: Expansion Of a PUBLIC SECTOR CHARGING LIT- TLE OR NO TUITION FEES.}

This is perhaps the most prevalent model of growth over the past half century. Countries make a financial commitment of public funds sufficient to expand their public sectors of tertiary education without requiring large or even significant cost sharing in the form of higher fees from students and families. In this approach, tuition fees represent Io percent or less of the resources used to pay for instructional and operational expenses (excluding research and other activities).

In the I950s and I96os, the United States employed such a strategy to make a transition to a mass education system beyond the secondary level. This model included the development of a community college system as well as the creation and expansion of four-year public institutions. In the past quarter century, this strategy has been used by several Scandinavian countries including Norway, Sweden, and Finland.

The critical component for successful implementation of this strategy is a country's willingness and ability to devote substantial levels of public resources (probably in excess of I.5 percent of GDP) to allow for expansion without significant cost sharing. In reality, most countries are not in a position to make such a commitment of public funding.

Model Two: Publicly financed fees repaid through the TAX SYSTEM ONCE STUDENTS GRADUATE.

Australia established a new model for growth in the late I980s when it introduced its Higher Education Contribution Scheme (HECS). This strategy recognized two realities. One was the financial reality that private resources were needed to supplement public resources to fuel the growth of higher education.
The other was the political reality that many students and their families were unwilling to pay traditional fees. To deal with these realities, Australia developed an approach in which the government would initially finance fees, with most of these students repaying the fees once they graduated as a percentage of their income through the tax system. England and Thailand introduced a similar system of publicly financed fees beginning in the academic year 2006 .

A key question with regard to publicly financed fees, like the model of public-sector expansion, is whether a country has enough resources to fund it. Under this approach, governments essentially are funding both sides of the tertiary financing equation-operational support of institutions and the payment of fees by students and families - until the stream of loan repayments is sufficient to provide significant private resources. Even a country as wealthy as Australia has found that it needed to reduce HECS subsidies by lowering the incomes that qualify for nonrepayment and raising the HECS fees to make the system sustainable. In addition, many Australian institutional officials would claim that public support of higher education has been reduced to make ends meet.

\section{MODEL THREE: INCREASED COST SHARING COMBINED WITH HIGHER LEVELS OF STUDENT AID.}

This model of growth is one in which more significant cost recovery through higher fees is introduced at a wide range of public institutions. This plan is usually combined with greater reliance on student aid to ensure that economically disadvantaged students are not discouraged from attending when higher fees are charged. Over the past quarter century, the United States, New Zealand, and Canada are examples of countries that successfully pursued this approach to expand resources to meet rapidly growing demand.

Raising fees for all public-sector students is typically thought of as the basic policy response for greater cost sharing. In reality, countries raise fees in a number of different ways to increase the degree of cost sharing. Many Eastern European countries established a system of parallel fees in which students who do not qualify for the "free seats" based on grades and merit can enroll in the same courses of study by paying tuition fees that are set at or near the full cost of education. This plan is not recommended as it introduces or reinforces system inequities.

However, other ways of raising fees selectively make a great deal of sense for spurring growth and introducing greater equity. These methods include dual fee systems in which students in state-funded fields pay low, subsidized fees, while students in high-demand fields such as business or law pay higher "market-based" fees equal or close to full costs. Australia is a prime example of a country that has moved to a dual fee structure in which HECS students pay (or repay) government-set fees, whereas all foreign students and a growing number of domestic students pay at much higher levels. Differential fees by level of study are another common strategy for increased 
cost sharing. Groups of students pay different levels of fees: lower fees for domestic undergraduates and higher fees for graduate students, international students, and in some instances adult learners.

MODEL FOUR: EXPANSION OF A PRIVATE SECTOR OF INSTITUTIONS.

This model of growth expands enrollments in private institutions to take up the slack created from restrictions in the size and growth of the public sector of tertiary education. This has occurred in a number of countries around the world either as a matter of deliberate government strategies or simply as an industry developing in response to unmet demand. In the Middle East and some countries in Asia, the number of private-sector institutions and students has grown particularly in vocational programs, although private universities have been the primary source of growth in some countries such as Japan and Korea. Poland is an example of an eastern European country that has become a mass higher education system largely through the growth of a private sector.

In some countries, the private institutions are for-profit while in others their organization is typically not-for-profit, with surpluses reinvested in the institution. What is common is that most enrollment growth occurs in the private sector while the number of students enrolling in public-sector institutions remains stable or grows very slowly as additional public funds are not made available. One way to encourage more enrollments in the private sector is to make students enrolling in these institutions eligible for the full range of student grants and loans. Another way to encourage private-sector growth is for governments to facilitate the approval of programs that meet minimal quality standards.

The four models of growth described above demonstrate that there are different routes for countries to achieve the goal of mass or universal tertiary education.

\section{Universities and Development: Goals of Success}

\section{Mohamed H. A. Hassan}

Mohamed H. A. Hassan is executive director of the Academy of Sciences for the Developing World (TWAS) in Trieste, Italy. E-mail: mhassan@twas.org. For additional information about TWAS, see www.twas.org.

Tn the I970s, universities in many developing countries 1 enjoyed strong support from their governments. Staffed by a youthful and well-trained faculty, equipped with adequate classrooms and laboratories, and spurred by the excitement and sense of purpose associated with new enterprises, institutions of higher education across the developing world seemed poised to gain additional strength in the future. For example, the University of Khartoum in Sudan, where I taught and served as dean of the school of mathematics for more than a decade, was one of the best universities not only in Africa but also throughout the developing world.

Throughout the late 1980 s and into the early 1990s, governments in many developing countries substantially reduced their investment in higher education.

So what happened? How did such promising circumstances turn into such a dismal situation in the late i980s and I990s? How did universities, especially universities in the world's poorest countries, become hollow, largely destitute institutions where little learning and even less research took place?

Part of the answer lies in forces well beyond the influence of scientists and scientific communities in developing countries. Political instability often accompanied by deadly violence; declining investments in higher education by both governments and international lending agencies; the rise of HIV/AIDS and other public health issues; and many other critical concerns, which demanded immediate responses, distracted attention from higher education and, more specifically, adversely impacted investments in science and technology in the developing world.

At the same time, aid agencies increasingly concluded that developing nations should focus on getting their economic house in order, usually by reducing governmental expenditures to curb public debt. They also came to believe that scientific research was a luxury that developing nations could not afford in light of the critical social and economic issues that they faced. The science and technology that developing countries needed, aid agencies reasoned, could be acquired from others.

As a result, throughout the late I980s and into the early I990s, governments in many developing countries substantially reduced their investment in higher education. Aid agencies, meanwhile, devalued the importance of building indigenous capacity in science and technology in the developing world.

The irony of this strategy was this: The critical issues that developing countries faced-whether a desire to reduce hunger and malnutrition, provide greater access to safe drinking water, curb disease and improve public health, or construct reliable energy systems-all necessitated the widespread applications of science and technology. Indeed, such efforts required not just any science and technology but appropriate 